\title{
PSYCHOLOGICAL CHARACTERISTICS OF PRIMARY AGE CHIILDREN AND THE SPECIFIC CHARACTERISTICS OF TEACHING A FOREIGN LANGUAGE
}

\author{
Po'latova Shahzoda Haydarovna ${ }^{1}$ \\ ${ }^{1}$ A teacher of ESP for Humanitarian Subjects \\ Foreign Languages Faculty \\ Bukhara State University \\ E-mail: shakhzodalove@gmail.com
}

\begin{abstract}
The article discusses the importance of developing English speaking skills in teaching foreign languages to different ages. Careful study and application of such types of speech as monologue, dialogue, public communication. It also discusses how to teach using a variety of methods and techniques in teaching young, middleaged, and older adults, and how to use effective teaching tools in shaping the speaking skills of these three categories.

Key words: speaking skill, monologue, dialogue, public communication, adults, teaching tools, learning
\end{abstract} process.

\section{I.Introduction}

The concept of the learning process includes the activities of teachers and students, as well as organizational forms of this process. In education, this process is called the academic year, academic quarter, lesson or course. A lesson is a part of a learning activity. Arabic lesson (madras - place of teaching, religious school; mudarris - teacher; tadris synonymous with such words as teaching or passing) is also called a lesson in colloquial language. The term training is synonymous with the word exercise. Exercises are training sessions. A foreign language lesson or class consists of a set of exercises.

Numerous books and articles have been written on the subject in general education, and in the methodology of teaching foreign languages, which is private education, many scientific works have been published in chapters and articles, and large pamphlets have been published. The subject of a foreign language is studied in class and in extracurricular activities (extracurricular activities are carried out under the guidance of a teacher and independently). Classes are legalized as compulsory. Optional classes were once a separate educational activity.

\section{II.Literature review}

The division into stages, on the one hand, takes into account the nature of foreign language teaching, on the other hand, the age of students. The age of the student is comprehensively developed in the deep theoretical and experimental research of psychologists. The organization of the process of teaching a foreign language is based on the scientific sources of psychology and anthropology.

Taking into account the age and personality of students, such as thinking, memory, perception, activity, the teacher takes a different approach to teaching a foreign language and acts rationally. The division of foreign language education into three stages serves this purpose.

The stages of acquiring speech activity are also considered in language learning. Emphasis is placed on the relationship between the volume of lexical and grammatical material and the types of speech activities. The basis for learning a foreign language is created; skills and abilities are gradually developed.

Thus, the traditional three stages in the organization of foreign language teaching are called primary, secondary and higher. At the same time, it is logical to recognize the stages of formation of speech skills in a foreign language as a conditionally two-centered process. In the first, they face a distinction between organizational and speech stages. Based on the data of psychology, pedagogy and teaching methods, a three-stage analysis of the process of foreign language teaching begins.

\section{III.Analysis}

Significant time and effort are expended in mastering language skills, such as writing and reading, along with the humble ability to speak and listen in a foreign language. At this stage, relatively more time is allocated in the curriculum. Classes are taught in small groups. At this stage, students develop stable listening and pronunciation skills. Speech and reading aloud are often practiced to create auditory representations of language units. It is known that other types of speech activities are taught through speaking.

At the elementary level, students are required to be able to listen to and understand the teacher's stories and instructions, to tell pictures based on the language material they have learned, to tell the content of the text, to have conversations on past topics, to read and understand the text is done. Acquires the skills to answer a given question, ask a question, agree or oppose an offer, and understand what a partner is saying in pairs. Oral and reading topics will focus on 
school and home. Lexical and grammatical material is mastered in the active minimum.

By the end of the first academic year, the student begins to practice reading. Reading rules are usually based on the acquisition of lexical and grammatical units, and when two or more linguistic examples appear, the corresponding rule is issued.

Acquires calligraphy and spelling skills by the end of VI grade. Homework assignments include written assignments and reading aloud to reinforce what is being learned in class. The most difficult part of the elementary methodology is whether the types of speech activities are taught equally or whether they are taught individually or sequentially. The complexity of the problem is also related to the question of whether it is necessary to move from oral speech to reading or vice versa. Two scientific terms are common in methodological theory and complex school practice: the oral introductory course and the oral advancement. The most pressing issues of the primary level are related to these two concepts. The existing literature covers a wide range of these types of primary education.

The methodical approach, which teaches oral speech for a period of time and then translates into written speech, is called an oral introductory course. There are textbooks that recommend only oral exercises for a quarter or even a year. In a number of countries, various versions of the oral course have been developed and introduced in the first academic year. Each of them was scientifically substantiated in the form of a methodical system. Much has been written about it in the methodology. In schools of Uzbekistan the teaching of foreign languages according to methodical criteria of oral promotion is accepted.

The methodical approach, which teaches oral speech for a period of time and then translates into written speech, is called an oral introductory course. There are textbooks that recommend only oral exercises for a quarter or even a year. In a number of countries, various versions of the oral course have been developed and introduced in the first academic year. Each of them was scientifically substantiated in the form of a methodical system. Much has been written about it in the methodology. In schools of Uzbekistan the teaching of foreign languages according to methodical criteria of oral promotion is accepted. In the 5th grade, the material learned through listening and speaking as a result of oral progress is given first in writing, then in reading, and in the 6th grade, after listening comprehension and speaking, reading and writing exercises are practiced. This stage, in which students of VII-IX grades of secondary school study, is, on the one hand, an intermediate period, and, on the other hand, a new stage in the development of speaking skills in a foreign language. This stage is the final stage of secondary school. There is a loss of interest in some subjects, including foreign languages. Consciousness increases in the study of language material.

At this stage, the study of active lexical and grammatical material continues. Oral communication retains its leading practical purpose and status as one of the most important educational tools. The position of learning as a skill changes, it begins to rise to the level of the main practical goal. Emphasis is placed on interesting and useful information from the written text. Thus, the effort and time spent on oral and reading skills will be equal. By the end of the seventh grade, the groundwork will be laid for reading to become a practical goal.

At the end of the second (intermediate) stage, students will be able to express themselves orally on a given topic, recite the content of a text they have heard or read, participate in a conversation, and write a letter. They practice expressing their attitudes, substantiating their point of view, and explaining the cause-and-effect relationship. You will need to be able to use appropriate cues during a conversation, use up to 7 cues in a pair of speeches, and be able to say up to 12 sentences in a single speech. When reading 3-4\% of unfamiliar words without a dictionary, to understand their meaning with the help of context or word-forming elements, when the amount of unfamiliar words is higher than above, with a dictionary read and understand.

In the eighth grade, almost all active grammatical events are studied. The grammatical unit previously studied lexically (as a typical sentence) is now generalized, if the example is sufficient. Verbal advancement continues within the boundaries of a session. Learners of English and French become more familiar with transcription due to the encounter of unfamiliar words in reading. In the eighth grade, they begin to use a bilingual dictionary and begin to work independently with the dictionary.

At the end of the intermediate stage, it is recommended to listen to the teacher's speech, which lasts up to three minutes, and listen independently in the classroom and in the foreign language room.

\section{IV.Discussion}

The increase in the weight of reading is manifested in an increase in the volume of the text, an increase in the total volume of reading, mainly reading silently at home. Familiar reading is formed. At the end of the stage begins reading with the elements of analysis. During this period, home translation is taught and checked in the classroom. Writing essays are practiced, discussed in class, and written at home. Due to the lack of weekly study hours, a lot of attention is paid to independent work at this stage. In grades V-IX, the topics "Environment" and "Our Country" will be the basis for speaking, listening, reading and writing. The studied lexical and grammatical material is the active minimum. At the intermediate stage, a certain level of mastery of point skills and abilities is completed. So, even in the middle stage, it is the basis of speaking and writing. This period, when the foreign language teaching course is completed, also has its own peculiarities. The curriculum achieves the ultimate goal of speaking skills. According to the characteristics of 16-18 year olds, reading meaningful texts becomes the primary task. 
This stage can be divided into two periods: the first half of the year (1st and 2nd quarters) and the period from the 3rd quarter to the end of the 3rd year. First-year students can usually come from different schools or classes. Because of the different levels of knowledge, they have to "equalize" their speaking skills. For half a year, they mostly go through a period of repetition. Depending on the personality of each lyceum and college first-year student, individual work is carried out (for example, the use of handouts, homework, extracurricular activities).

The grammatical phenomena studied are included in the passive minimum, that is, they are intended to be recognized during listening or teaching comprehension. New meanings of polysemantic words, previously mastered in one sense, are revealed. Half of the vocabulary is actively assimilated and the rest is assimilated passively. Reading acquires the right of primary practical purpose. Listening comprehension and speaking skills are developed on the material read and the topic of reading. Most one-on-one exercises are performed within the context of the text.

Demands on texts are growing: the language of the text is becoming more complex, written texts in the style of the book play a key role, in addition to the adapted passages, the original texts are read. Excerpts from fiction increase the weight of popular science texts related to the life of the countries where the language is studied. Articles from the press are selected. They are intended for reading. Homework reading begins. Pre-text and post-text exercises are performed in class. Texts read in the classroom are small in size and are recommended to practice reading speed. Awareness is enhanced by learning a language that has not been observed in the previous stages. Reading rules are, in a sense, theoretically regulated, with high school students reading new words independently. Grammar knowledge is also generalized to the rules; various linguistic tables are compiled and applied in practice. They work using grammar reference books.

"Total Physical Response", developed by American psychologist James Asher in 1963, is a method of language teaching. Richard and Roger argued that this method was built around the coordinates of speech and movement, and that it helped to teach language through physical movement. The goal of TPR is the fluency of language teaching skills. Even Asher does not use the term "method". He calls TPR a language strategy or a teacher's tool combined with various strategies. According to him, there are no methods of teaching a foreign language. Because the method refers to the formula and the formula turns to science. Teaching is an art, not a science.

Total Physical Response, developed by American psychologist James Asher in 1963, is a method of language teaching. Richard and Roger argued that this method was built around the coordinates of speech and movement, and that it helped to teach language through physical movement. The goal of TPR is the fluency of language teaching skills. Even Asher does not use the term "method". He calls TPR a language strategy or a teacher's tool combined with various strategies. According to him, there are no methods of teaching a foreign language. Because the method refers to the formula and the formula turns to science. Teaching is an art, not a science.

When this is done successfully, the teacher stops doing these actions and gives instructions only in words. For two or three actions, the command is a noisy sequence.

For example: 0 `rningizdan turing (stand up),

divanni yoniga boring (walk to the sofa),

o`tiring (sit down).

The order of the commands should change until the students remember the mixed order.

For example: sakrang (jump),

eshikni ko'rsating (point to the door),

More complex, sometimes imaginative, actions are required.

For example: mashinaga o`tiring (sit in the car),

kalitni burang (turn the key),

atrofga qarang (look around),

ikki marta signal chaling (honk the horn twice).

Vocabulary and grammar should be consistent. For example, conditional connectors:

Agar bugun juma bo`lsa, sakrang va qarsak chaling (If today is Friday, jump up and clap your hands). Instructions on How to make things or Problem solving games can also be easily turned to TPR. This process only happens when all the students in the class want to talk.

\section{V.Conclusion}

As we have seen, group discussions can take a variety of formats and are useful for all types of students. They can be done in preparation for job interviews or as extended speaking practice simply to increase fluency. It is important to consider the different sub-skills that are involved in participating in a group discussion and ensure that you do activities that address each of these. Additionally, structuring and varying the way that feedback is given will help the students to identify areas for improvement.

\section{References:}

1. Rajabova M.B. Goethe and the East. International scientific-practical conference "XL international conference dedicated to the problems of social sciences" (March 31, 2016) Moscow -2016. 43-38pp. 
2. Marifat Bakaevna Rajabova. From the history of the views of the great thinkers of the East on education and upbringing. International scientific and practical conference "Fundamental and applied research: a new word in science", Moscow, December 15, 2014. Pp. 125-132.

3. Rajabova Marifat Bakaevna. Artistic interpretation of the mythonyms of angel and devil in the works of A.Navoi. Middle European Scientific Bulletin, ISSN 2694-9970. VOLUME 5, OCTOBER 2020. Pp. 135-131

4. Jalolov J.J. Methods of teaching foreign languages: a textbook for students of foreign language universities (faculties) / J.J.Jalolov. - Tashkent: “O’qituvchi”, 2012.

5. Muhammadjon Khodjaev "Methods of teaching a foreign language" - Tashkent: "O'qituvchi”, 2013.

6. Boice, R. (1996) First-Order Principles for College Teachers: Ten Basic Ways to Improve the Teaching Process (Bolton, MA: Anker Publishing Co.)

7. Handelsman, J., Miller, S., \& Pfund, C. (2006) Scientific Teaching: Diversity, Assessment, Active Learning (New York: W.H. Freeman \& Co.)

8. Sellers, S.L., Roberts, J., Giovanetto, L., Friedrich, K. \& Hammargren, C. (2007) Reaching All Students-A Resource for Teaching in Science, Technology, Engineering \& Mathematics (Second Edition) (Madison, WI: Center for the Integration of Research, Teaching, and Learning)

9. Steinert, Y. (2004) Student perceptions of effective small group teaching. Medical Education, 38:286-293.

10. Tuckman, B. \& Jensen, M. (1977) Stages of Small Group Development. Group and Organizational Studies, vol. 2, pp.419-427.

11. Habeshaw, S., Habeshaw, T., \& Gibbs, G. (1984). 53 Interesting Things to Do in Your Seminars \& Tutorials. Bristol: Technical and Educational Services Ltd.

12. Johnson, D. W., Johnson, R. T., and Smith, K. A. (1991). Cooperative Learning: Increasing College Faculty Instructional Productivity. ASHE-ERIC Higher Education Report No.4. Washington, D.C.: School of Education and Human Development, George Washington University.

13. Silberman, M. (1996). Active Learning: 101 Strategies to Teach Any Subject. Boston: Allyn and Bacon.

14. Z.R.Murodova The formation and definition of the intellectual potential in education. ISJ Theoretical \& Applied science. Philadelphia, USA. 2020. P. 113-116.

15. Muradova F.R. Using the capabilities of virtual laboratories in the educational process. Academicia. Impact Factor 7, India, 2020. Vol.10 Issue 8, p. 347-352.

16. Muradova F.R. The methodology of using virtual laboratories in the educational process. Modern views and research. Materials of the international scientific and practical conference. - England. 2020, p. 24-26.

17. Muradova F.R. Educational laboratory as a modern form of educational activity organization. XXII International scientific and practical conference "International scientific review of the problems and prospects of modern science and education”. - USA, Boston. 2020, p. 41-43.

18. Khudayberganova, G. N. (2019). АНАЛИЗ ФЕНОМЕНА АСКЕТИЗМА В УЧЕНИЯХ МИРОВЫХ РЕЛИГИЙ. Theoretical \& Applied Science, (12), 579-582.

19. KHUDAYBERGANOVA, G. (2018). ASCETICISM IN WORLD RELIGIOUS TRADITIONS. The Light of Islam, 2018(4), 23-28.

20. Очилова, Н. Р., Мамасалиев, М. М., \& Астанов, А. Р. (2020). ВНИМАНИЕ ВОСПИТАНИЮ ГАРМОНИЧНО РАЗВИТОГО МОЛОДОГО ПОКОЛЕНИЯ. International Independent Scientific Journal, (14-2), 18-20.

21. Mamasaliev, M. M., \& Elboeva, S. B. (2019). RELIGIOUS-PHILOSOPHICAL DOCTRINES OF SARVEPALLI RADHAKRISHNAN. Theoretical \& Applied Science, (11), 339-342.

22. Мамасалиев, М. М., \& Бўриев, И. И. (2019). ИНФОРМАЦИОННАЯ БЕЗОПАСНОСТЬ УЧАЩИХСЯОДНО ИЗ ОСНОВНЫХ НАПРАВЛЕНИЙ ДЕЯТЕЛЬНОСТИ ПЕДАГОГА. Іn ФУНДАМЕНТАЛЬНЫЕ ОСНОВЫ ИННОВАЦИОННОГО РАЗВИТИЯ НАУКИ И ОБРАЗОВАНИЯ (pp. 188-190). 